\title{
Relationship between atopic manifestations, family history of atopic disease and cord blood IgE levels in children
}

\author{
Tisnasari Hafsah, Myrna Soepriadi, Budi Setiabudiawan, Herry Garna
}

\begin{abstract}
Background The incidence of atopic disease tends to increase over the past few decades and its morbidity interferes with the quality of life and health. Prediction of the disease is important for early prevention.

Objective To evaluate the relationship between atopic manifestations, family history $(\mathrm{FH})$ of atopic disease and cord blood IgE (CB-IgE) levels.

Methods We conducted an analytic observational study with cohort retrospective design on children with an average age of 3 years whose CB-IgE had been measured at delivery in Kiaracondong Primary Health Care during October-December 2004. Manifestations of atopic disease were recorded using ISAAC questionaire for allergy. Chi-square, Mann-Whitney test, and logistic regression analysis were used for analysis.

Results Cord blood IgE was measured on 124 children after birth. Only 94 children (76\%) fulfilled the inclusion criteria. Atopic disease was found in 17 children (18\%), consisting of 8 children with atopic dermatitis, 4 with allergic rhinitis, and 5 suffered from both. There were significant differences in the mean value of $\mathrm{CB}$ $\operatorname{IgE}\left(\mathrm{Z}_{\mathrm{M}-\mathrm{W}}=4.60 ; \mathrm{P}<0.001\right)$ and $\mathrm{FH}\left(\mathrm{x}^{2}=19.059 ; \mathrm{P}<0.001\right)$ between atopic and non atopic children. Cut off point of the CBIgE concentration was $1.4 \mathrm{IU} / \mathrm{mL}$ (77.7\%). The highest probability for atopic manifestations was found in children who had high CB-IgE and positive $\mathrm{FH}(\mathrm{P}=45 \%)$. Relative risk of children with high CB-IgE level in positive $\mathrm{FH}$ group was 3.636 (95\% CI 0.943;14.016).

Conclusion CB-IgE level and family history of atopic disease are risk factors for the development of atopic manifestation. [Paediatr Indones 2007;47:278-282].
\end{abstract}

Keywords: atopic disease, cord blood IgE, family history

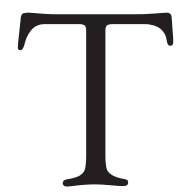

The incidence of atopic diseases has been increasing dramatically over the past few decades. ${ }^{1,2}$ Although it doesn't cause significant mortality, its morbidity disturbs the quality of life ${ }^{3}$ and increases health cost. ${ }^{3,4}$ The prevalence of childhood atopic disease showed that atopic eczema is $20 \%$ in boys (12\% in the year before study), and $19 \%$ in girls ( $11 \%$ in the year before 2000). ${ }^{2}$ Allergic asthma varies between $8 \%$ and $12 \%$, especially in industrialized world. ${ }^{5}$ Seasonal allergic rhinitis (hay fever) is around $10-12 \%$, as for perennial allergic rhinitis. ${ }^{6}$ The prevalence reached a significant increase $(6-14 \%)$ at the age of about 3 years old. ${ }^{7}$

Factors influencing the development of atopic manifestations might be internal ${ }^{2,8}$ or external factors. ${ }^{2,9}$ Atopy is a hereditary predisposition to produce $\operatorname{IgE}$ antibodies against common environmental allergens and manifests as one or more atopic diseases (i.e., allergic rhinitis, asthma, and atopic

From The Department of Child Health, Medical School, Padjadjaran University, Bandung, Indonesia.

Reprint requests to: Tisnasari Hafsah, MD, Department of Child Health, Medical School, Padjadjaran University, Hasan Sadikin Hospital, Jl. Pasteur No.38, Bandung, Indonesia. Tel. 61-22-2034426. Fax. 61-22. 2035957. 
dermatitis). ${ }^{10-12}$ Children with family history of atopic disease are at high risk to develop the disease. ${ }^{4,13,14}$ Elevated serum IgE is the hallmark of atopic disease. ${ }^{15}$ Initial exposure to allergen (which can occur with priming in utero) leads to sensitization ${ }^{16}$ and production of IgE antibodies. ${ }^{14}$ During subsequent allergen exposures, allergic inflammation is initiated by cross-linking the allergen with $\operatorname{IgE}$ antibodies, followed by mediator release which results in a cutaneous wheal-and-flare reaction, sneezing and runny nose, or wheezing within minutes. ${ }^{17}$ For preventive measures, IgE levels are determined as soon as possible, i.e. by analyzing cord blood IgE (CB-IgE).

The role of CB-IgE as a risk factor or predictor of atopic disease has been widely discussed. Croner et $a^{18}$ who screened 1,701 newborns found atopic disease developed in 73\% infants with high CB-IgE level and positive family history, compared to $3 \%$ of infants with low CB-IgE level and no FH. However, other studies couldn't find any association between elevated CB IgE level and atopic manifestations. ${ }^{19,20}$

This study aimed to determine the relationship of atopic disease in children with cord blood IgE (CB$\mathrm{IgE}$ ) level and family history of atopic disease.

\section{Methods}

This was a retrospective cohort study performed from October-December 2004. The subjects were children of 3 years old, whose CB-IgE were already measured at delivery in Kiaracondong Primary Health Care. Data were obtained from a previous report. ${ }^{21}$ The inclusion criteria were those whose parents/caregivers agreed to sign written informed consent. Subjects were excluded when they could not be found or moved from Bandung. The initial study consisted of 124 children with equal numbers of positive and negative $\mathrm{FH}$ of atopic disease. Total cord blood $\operatorname{IgE}$ was measured by Cobas Core Kit to detect the IgE by ELISA.

\section{Determination of atopic disease}

Manifestation of atopic disease was determined using the International Study of Asthma and Allergies in Childhood (ISAAC) standardized questionnaire for allergy. ${ }^{22}$ Interview was done by the authors and assisted by trained medical staff to collect general data including children's weight and height.

Allergic asthma was diagnosed by recurrent wheezing and/or cough more than three nights in a series. Atopic dermatitis was defined as itchy rash occurring on typical distribution, such as face, neck, flexural and extensor area, and buttocks. Allergic rhinitis/rhino conjunctivitis defined as a nasal discharge, or attacks of sneezing and itching eyes without respiratory infection.

\section{Statistical analysis}

Data were analyzed with SPSS version 10.0. Descriptive statistics, including mean and range were calculated for subjects' characteristics. The differentiation of CBIgE levels and $\mathrm{FH}$ between the atopic and non atopic children were analyzed by comparative statistics (MannWhitney and chi square test), and considered as significant if $\mathrm{P}<0.05$. Prediction on the incidence of atopic disease was calculated by determining the cut off point of CB-IgE and logistic regression analysis.

\section{Ethical approval}

This study received approval from the Health Study Ethical Committee, at Faculty of Medicine University of Padjadjaran/Hasan Sadikin General Hospital Bandung.

Table 1. Characteristics of subjects

\begin{tabular}{lccc}
\hline $\begin{array}{l}\text { Characteristics } \\
\text { of subjects }\end{array}$ & Subjects & Excluded & Significance \\
\hline $\begin{array}{l}\text { Sex } \\
\quad \text { Boys }\end{array}$ & $52(81 \%)$ & $12(19 \%)$ & $\mathrm{x}^{2}=2.137$ \\
$\quad$ Girls & $42(70 \%)$ & $18(30 \%)$ & $\mathrm{P}=0.144$ \\
$\begin{array}{l}\text { Family history of } \\
\text { atopic disease }\end{array}$ & & & \\
$\quad$ Yes & $49(79 \%)$ & $13(21 \%)$ & $\mathrm{x}^{2}=0.704$ \\
$\quad$ No & $45(73 \%)$ & $17(27 \%)$ & $\mathrm{P}=0.144$ \\
$\begin{array}{l}\text { Cord blood IgE level } \\
\text { (IU/mL) }\end{array}$ & & & \\
$\quad$ Mean (SD) & $2.022(2.333)$ & $1.290(1.674)$ & $\mathrm{Z}_{\mathrm{M}-\mathrm{W}}=-1.654$ \\
$\quad$ Median & 0.850 & 1.150 & $\mathrm{P}=0.098$ \\
$\quad$ Range & $0-7.6$ & $0-13.4$ & \\
Age (months) & & & \\
$\quad$ Mean (SD) & $39.7(1.6)$ & $39.9(1.4)$ & $\mathrm{t}=-0,649$ \\
$\quad$ Range & $36-42$ & $37-42$ & $\mathrm{P}=0.518$ \\
$\quad$ Total subjects & $94(76 \%)$ & $30(24 \%)$ & \\
\hline
\end{tabular}

Note: $\mathrm{Z}_{\mathrm{M}-\mathrm{W}}=$ Mann-Whitney test; $\mathrm{x}^{2}=$ chi-square test; $\mathrm{t}=\mathrm{t}$ test 


\section{Results}

Out of 124 subjects, 94 (76\%) fulfilled the inclusion criteria. The characteristics of subjects who were included and excluded in this study are presented in Table 1 . The characteristics include sex, family history of atopic disease and CB IgE level. There was no statistical difference between atopic and non atopic children incidence.

Manifestations of atopic disease occurred in 17/ 94 children, as seen in Figure 1. Atopic dermatitis was the most common symptom (8 children), followed by both atopic dermatitis and allergic rhinitis ( 5 children), and allergic rhinitis (4 children).

Comparative statistics were used to evaluate the association between family history and atopic manifestations (Table 2). Association between mean value of cord blood IgE levels in atopic and non atopic children is presented in Table 3.

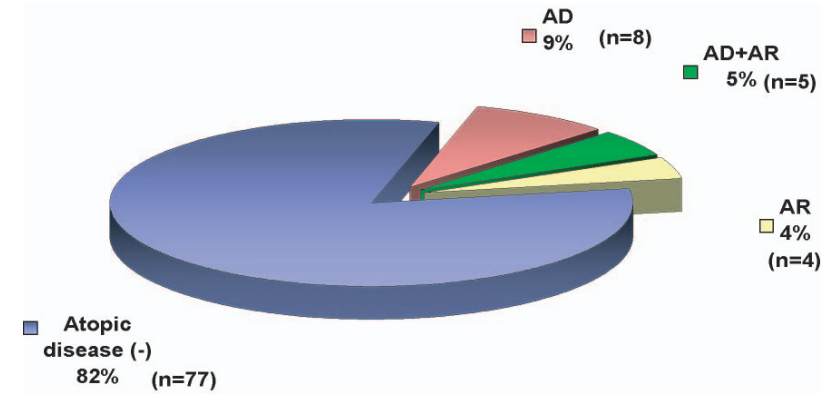

Figure 1. Atopic manifestation in children

Note: AD: Atopic Dermatitis; AR: Allergic Rhinitis

Table 2. Atopic manifestation in children based on family history of atopic disease

\begin{tabular}{cccc}
\hline \multicolumn{3}{c}{ Family History } \\
& $(+)$ & $(-)$ & \\
\hline $\begin{array}{c}\text { Atopic Dermatitis } \\
(+)\end{array}$ & 13 & 0 & $\mathrm{x}^{2}=13.855$ \\
$(-)$ & 36 & 45 & $\mathrm{P}<0.001$ \\
$\begin{array}{c}\text { Allergic Rhinitis } \\
(+)\end{array}$ & 9 & 0 & $\mathrm{x}^{2}=9.140$ \\
$(-)$ & 40 & 45 & $\mathrm{P}=0.003$ \\
Atopic disease & & & \\
$(+)$ & 17 & 0 & $\mathrm{x}^{2}=19.059$ \\
$(-)$ & 32 & 45 & $\mathrm{P}<0.001$ \\
\hline
\end{tabular}

Children with family history of atopic disease showed higher incidence of atopic manifestations $(\mathrm{P}<0.001)$.

Mean value of cord blood IgE levels were also significantly higher in children with atopic manifestations than in non atopic children.

Determining the cut off point of cord blood IgE, the accuracy was highest at level $1.4 \mathrm{IU} / \mathrm{mL}(77.7 \%)$, with sensitivity of $88.2 \%$, specificity of $75.3 \%$. This cut off value pointed out the positive predictive value by $44.1 \%$ and negative predictive value by $96.7 \%$. Based on this cut off value, CB-IgE were determined high $(>1.4 \mathrm{IU} / \mathrm{mL})$ in 34 children, and low $(=1.4 \mathrm{IU} /$ $\mathrm{mL}$ ) in 60 children. The incidence of atopy was highest in children with high levels of cord blood IgE (15 out of 17 atopic children) compared to 19 out of 77 in non atopic children. Fifteen of 33 children with positive $\mathrm{FH}$ and high $\mathrm{CB}-\mathrm{IgE}$ levels developed atopic disease. None of negative FH and low CB-IgE levels $(n=44)$ developed atopic manifestations. (Figure 2).

By logistic regression analysis, the highest prediction of atopic disease was found with $(+) \mathrm{FH}$ and high CB-IgE $(\mathrm{P}=45 \%)$, Table 4.

Table 3. Mean value of cord blood IgE levels in several atopic manifestations

\begin{tabular}{|c|c|c|c|}
\hline & \multicolumn{2}{|c|}{ Atopic manifestation } & \\
\hline & Atopic Dermatitis & & \\
\hline X (SD) & $3.738(2.186)$ & $1.747(2.248)$ & $Z_{M-W}=-3.895$ \\
\hline Median & 3.4 & 1.1 & $\mathrm{P}<0.001$ \\
\hline Range & $1.4-8.5$ & $0-13.4$ & \\
\hline & Allergic Rhinitis & & \\
\hline$X(S D)$ & 4.556 (3.623) & $1.754(2.004)$ & $Z_{M-W}=4.60$ \\
\hline Median & 3.4 & 1.1 & $P<0.001$ \\
\hline Range & 1.3-13.4 & $0-9.6$ & \\
\hline & Atopic disease & & \\
\hline $\mathrm{X}(\mathrm{SD})$ & $4.171(3.11)$ & $1.548(1.833)$ & $\mathrm{Z}_{\mathrm{M}-\mathrm{W}}=4.60$ \\
\hline Median & 3.4 & 1.0 & $P<0.001$ \\
\hline Range & $1.3-13.4$ & $0-9.6$ & \\
\hline
\end{tabular}

Table 4. Prediction of atopic disease based on family history and CB-lgE levels.

\begin{tabular}{ccc}
\hline $\begin{array}{c}\text { Family History of } \\
\text { Atopic Disease }\end{array}$ & $\begin{array}{c}\text { Cord Blood } \\
\text { IgE Level }\end{array}$ & $\begin{array}{c}\text { Prediction of } \\
\text { Atopic Disease }\end{array}$ \\
\hline Yes & High & 0.45 \\
Yes & Low & 0.12 \\
No & High & 0.00007 \\
No & Low & 0.00001 \\
\hline
\end{tabular}

Note: Yes/High=1; No /Low=0 


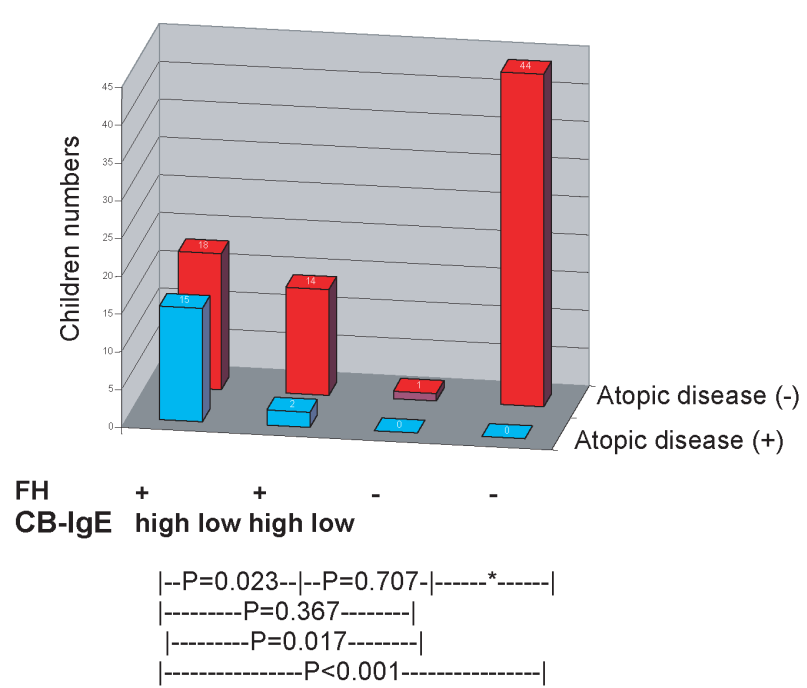

Figure 2. Developed atopic manifestations

$$
\begin{array}{ll}
\text { Note: }{ }^{*} & =\text { can not be analyzed } \\
\text { FH } & =\text { family history of atopic disease } \\
\text { CB-IgE } & =\text { cord blood IgE }
\end{array}
$$

The relative risk of children with high CB-IgE level exclusively in positive family history of atopic disease group $(\mathrm{n}=49)$ was $3.636(95 \%$ CI 0.943;14.016).

\section{Discussion}

Of the 94 children recruited, atopic disease was found in $18 \%$, with atopic dermatitis as the most common manifestation. This was quite high since this study was done on three year old children, when almost all atopic manifestation arise in the natural history of atopic march. ${ }^{7}$ If the data was collected when they were younger (i.e at 18 months), atopic manifestation might be less. In fact our study found that some manifested after the age of two. Other studies showed different finding. Croner ${ }^{18}$ found $8 \%$ children developed obvious or probable atopic disease, predominantly atopic dermatitis and bronchial asthma during the first 18 months of life, while other investigators found incidence of $12.9 \%$ and $36.6 \% .19,20$ Great variations of the definition of atopy between the different studies could interfere with the results. Our study used ISAAC standardized questionnaire for allergy which had been validated to determine the incidence of atopic manifestation. However, other tests are also useful in confirming the precise diagnosis, such as the skin prick test.

Genetic factors play an important role in the development of atopic disease. Atopic manifestations in children with family history of atopic disease was highly significant in our study $(\mathrm{P}<0.001)$.

In children with atopy, there is no doubt that elevated total IgE level has positive association with disease manifestation. An increase in IgE level points out evidence of sensitization which could occur with priming in utero. ${ }^{8,14,16}$ Cord blood IgE measurements in several studies showed different results. ${ }^{18-20} \mathrm{IgE}$ screening in 1,701 newborn infants noted that $70 \%$ infants with high cord blood IgE concentration developed obvious or probable atopic disease during the observation period, ${ }^{18}$ while others reported otherwise. ${ }^{19,20}$ Many factors might influence the outcome, such as laboratory methods, blood sampling techniques, cut off values and also precise criteria of atopic diagnosis. By using a level of $1.4 \mathrm{IU} / \mathrm{ml} \mathrm{CB}-\mathrm{IgE}$ concentration as cut off value in our study (which was different from other reports), significant differences were noticed. The predictive value was quite poor (44.1\%), however measuring CB-IgE at delivery should have significant meaning for identifying risk factor in infants.

Children with positive $\mathrm{FH}$ and high $\mathrm{CB}-\mathrm{IgE}$ levels developed atopic disease more often ${ }^{18}$ as found in our study $(\mathrm{P}=45 \%)$.

Expression of Th2-skewed immunity to ubiquitous environmental allergen is the hallmark of the atopic phenotype, in contrasts with the balanced Th1/Th2 pattern in normal individuals. Synthesis of IgE and clinical manifestations depend on the interaction of multiple gene products with environmental allergens. ${ }^{2}$ The fetus is known to synthesize IgE from the 11th gestational week. The study by Croner et all ${ }^{18} \mathrm{did}$ not suggest that IgE could be transmitted across the placental barier. Assuming that sensitization can occur in fetal life, the relative risk for atopic manifestation in children with (+) $\mathrm{FH}$ and increased CB-IgE level should be higher than those without. In our study the relative risk was 3.636 (95\% CI 0.943;14.016). However, the evidence of fetal specific sensitization to certain allergens was unproven, since the cord blood specific IgE were not measured in this study. Overall, our findings may be useful to plan early prevention ${ }^{22,23}$ 
in children who might have atopic disease later. The cut off value of cord blood IgE in this study should be determined further. For appropriate recommendations, further investigation with larger population is necessary.

In conclusion CB-IgE level and family history of atopic disease are risk fators for the development of atopic manifestation.

\section{Acknowledgments}

We would like extend our gratitude to the headmaster and staffs of Kiaracondong Primary Health Care for being helpful and supporting during this study.

\section{References}

1. ETAC Study group. Determinants of total and specific IgE in infants with atopic dermatitis. Pediatr Allergy Immunol 1997; 8:177-84.

2. Yadav M. Maternal factors in atopy. Medical Progress 2000;3:15-22.

3. Kristal L., Klein PA. Atopic dermatitis in infants and children. An update. Ped Clin North Am 2000;47:877-95.

4. The International Study of Asthma and Allergies in Childhood (ISAAC) Steering Committee. Lancet 1998; 351:1225-32.

5. Kay J, Gawkrodger DJ, Mortimer MJ, Jaron AG. The prevalence of childhood atopic eczema in general population. J Am Acad Dermatol 1994; 30:35-9.

6. Arshad SH, Babu KS, Holgate. Anti-IgE therapy in asthma and allergy. London: Martin Dunitz; 2001.

7. Wahn U, Matius E. Current reviews of allergy and clinical immunology. Childhood risk factors for atopy and the importance of early intervention. J Allergy Clin Immunol 2001;107:67-74.

8. Hopkin JM. Genetics of atopy. Pediatr Allergy Immunol 1995;6:139-44.

9. Morgan J, Williams P, Noris F, Williams CM, Larkin M, Hampton S. Eczema and early solid feeding in peterm infants. Arch Dis Child 2004;89:309-14.

10. Johansson SGO, Hourihane JO'B, Bousquet J, BruijnzeelKoomen C, Dreborg S, Haahtela T, et al. A revised nomenclature for allergy. An EAACI position statement from the EAACI nomenclature task force. Allergy 2001;56:813-24.

11. Johansson SGO, Bieber T, Dahl R, Freidmann PS, Lanier $\mathrm{BQ}$, Locley RF, et al. Revised nomenclature for allergy for global use: report of the nomenclature review committee of the World Allergy Organization, October 2003. J Allergy Clin Immunol 2004;113:832-6.

12. Terr AI. The atopic diseases. In: Parslow TG, Stites DP, Terr AI, Imboden JB, editors. Medical immunology. $10^{\text {th }}$ ed. New York: McGraw-Hill Co; 2001. p. 349-69.

13. Kjellman NAM, Johansson SGO. IgE and atopic allergy in newborn and infants with a family history of atopic disease. Acta Pediatr Scand 1976;65:601-7.

14. Savelkoul HFJ, Neijens HJ. Immune responses during allergic sensitization and the development of atopy. Allergy 2000;55:989-97.

15. Gerrard JW, Horne S, Vickers P, MacKenzie JWA, Goluboff $\mathrm{N}$, Garson JZ, et al. Serum IgE levels in parents and children. J Pediatr 1974;85:660-3.

16. Jones CA, Holloway JA, Warner JO. Does atopic disease start in foetal life? Allergy 2000;55:2-10.

17. Kay AB. Allergy and allergic diseases. Advances in immunology. N Engl J Med 2001;1:30-7.

18. Croner S, Kjellman NIM, Eriksson B, Roth A. IgE screening in 1701 newborn infants and the development of atopic disease during infancy. Arch Dis Child 1982;57:364-8.

19. Edenharter G, Bergmann RL, Bergmann KE, Wahn U, Fostr J, Zepp F, et al. Cord blood IgE as risk factor and predictor for atopic diseases. Clin Exp Allergy 1998;28:671-8.

20. Eiriksson TH, Sigurgeisson B, Sigfusson A, Valdimarsson H. Cord blood IgE levels are influenced by gestational age but do not predict allergic manifestations in infants. Pediatr Allergy Immunol 1994;5:5-10.

21. Hutapea AT, Setiabudiawan B, Soepriadi M, Rustama DS. Association between cord blood IgE levels in newborns and family history of atopic diseases. Paediatr Indones 2006;46:199-203.

22. Asher MI, Keil U, Anderson HR, Beasley R, Crane J, Martinez $\mathrm{F}$, et al. International study of asthma and allergies in childhood (ISAAC): rationale and methods. Eur Respir J 1995;8:483-91.

23. Zeiger RS. Food allergen avoidance in the prevention of food allergy in infants and children. Pediatrics 2003; 111:1662-71. 